\title{
関東甲信地方の降雹について (3)*
}

\author{
小 元 敬 男** \\ （国立防災科学技術センター）
}

Hailstorms in the Kanto-Koshin District (3)

Yukio Омото

(National Research Center for Disaster Prevention, Tokyo, Japan)

\section{1.はしがき}

北関東の農業関係者の中には雹道（ひょらみち），す なわち雹雲が頻繁に通る所, あるいは周辺に較べて雹害 の発生が格段に多い地域があると信じている人が多い。 雹道は谷沿いや川沿い, または高圧線沿いに出来ると彼 等はいう。気象俚言はその土地に住む人々の長い年月に わたる生活体験から生まれたものであつて, 研究価值の ある貴重な情報である。しかしながら人間の記憶に頼つ ていることが多いため瞹昧な点もあり，また限られた範 囲内でのことであるから，これを一般論とするのは危険 である。俚言の根拠の追求とその正当性の確認は, やは り気象官署の観測資料に基ついて科学的に為されるべき である。

雹道の位置がわかると, 降䨠系の行動を研究するため の野外観測区域や，降雹抑制の野外実験区域の選定に役 立つ。そこで，1960～1969年の10年間の暖候期を対象に 東京管区気象台発行の異常気象揖よび異常現象報告を基 に雹道の確認とその位置の決定を試みた。

\section{2. 資料の精度}

この報告に示した各種の頻度分布図は, 上述の資料か ら作成した降雹日毎の分布から求めたものである。これ 等の報告に記載されている降雹状況は時には詳しく, 時 には極めて大雑把であるため，これに基ついて作成した 降䨞日毎の分布図の精度は日によつて異なるものとなつ た。筆者は先に降雱日数の分布を作成するに際し, 区内

** 農業技術研究所気像科 (併任)

* 昭和 45 年 7 月 17 日 関東支部会にて発表
観測所の降䨠日数をそのまま用いた分布図 ${ }^{5)}$ や降雹日毎 の分布図から地域頻度分布図（任意地点から $10 \mathrm{~km}$ 以内 の降雹日数) ${ }^{7}$ を作成してみたが，いずれの方法でも雱 道を見つけることは出来なかつた。今回は降雹日毎の分 布を単純に重祆合わせて頻度分布を求めてみた。第 1 図 がその結果である。精度の異なる資料を基にして作成し たものであるから, 分布図中の細かい特徵は無視すべき である。

\section{3. 関東甲信地方における霄道}

第 1 図で特に注目に値するのは, 頻度分布に筋状の特 徵が明瞭に表われている点である。雹害頻度の大きい帯 状の地帯は各々, 明白に雹道に対応する。図中, 群馬南 部, 埼玉北部执よび栃木東部では, 降雹日数の多い場所 が広範囲にわたつており，筋状構造が不明瞭である。こ れは幾筋もの雹道が接近したり交錯したりしているため である。こうした地域における雱道を見い出すため, 移 動方向別の頻度分布図を作成し, 検討した。以下に, 東 進型, 東南東進型および南東進型について, 得られた結 果を述べる。

第 2 図は東進型の頻度分布図である。但しここには東 進した霓雲全部が示されているわけではない。東進した ことが確実な場合とほぼ間違いない場合のみを示してあ る。この図から, 長野盆地 (北信地方) と上田・佐久盈 地では東進型がひんぱんに発生していることがわかる。 他に, 碓隶峠から茨城県中部に延びる地帯と雲取山から 埼玉南部を経て茨城南部に達する地带も注目されるが, いずれも頻度は極めて少なく, 雹道と呼ぶには抵抗を感 じる。しかし, 霄は伴わないが一般に雷雲の通路の様に 


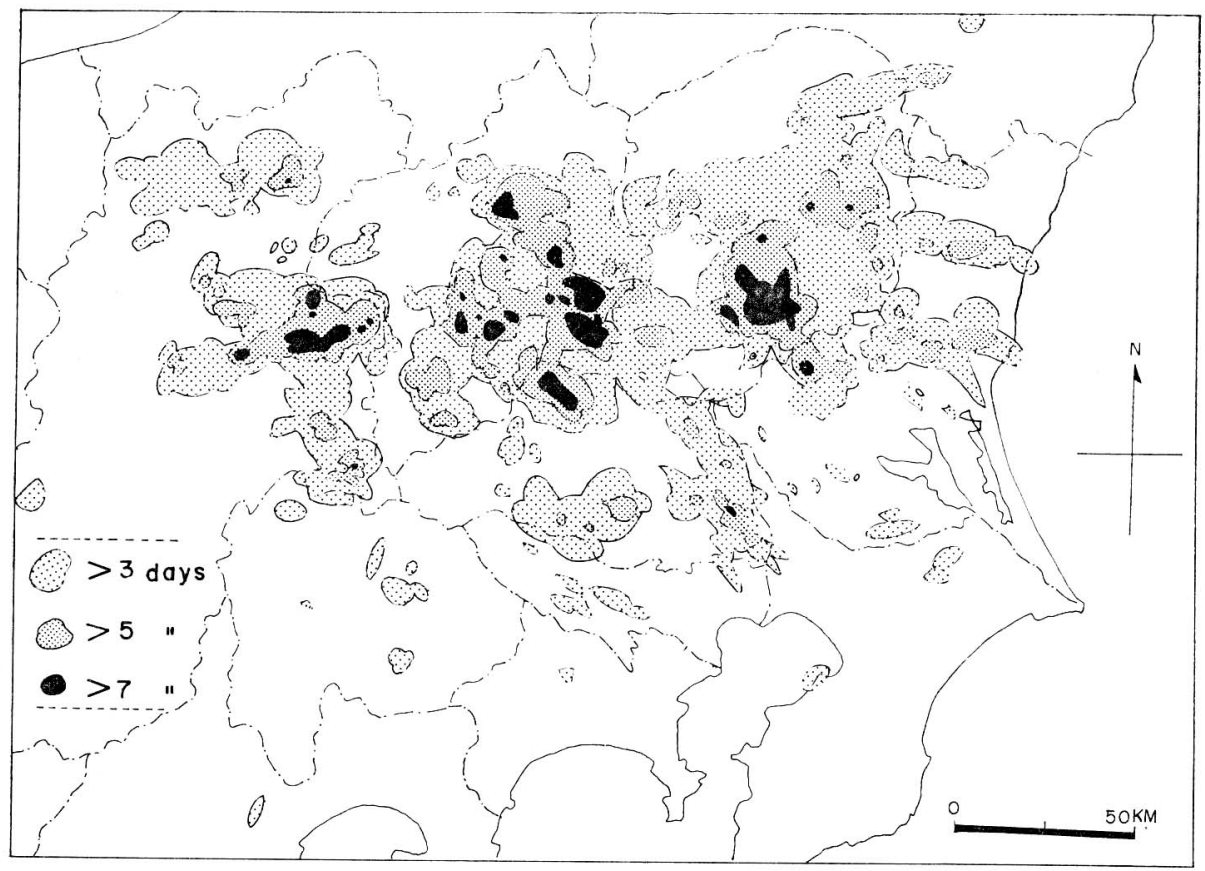

Fig. 1. Distribution of number of days with hail in warm seasons (April-September) of $1960-1969$.



Fig. 2. Frequency of eastward moving hailstorms(1960-1969). Only cases when the direction of movements were known are shown.

なつている地帯なので, 以下では準䨌道と呼ぶことにす る。

第 3 図は東南東進型の降䨌例を集めたものである。群 馬県南東部と栃木県北部から茨城県中部に, 杤木県中部 から茨城県中部に延びる雱道があることが分かる。

第 4 図は南東進型の頻度分布図である。第 2 ・ 3 図々 較べてみると, 関東平野では南東進する降霨系が最も多 いことがわかる。また，南東進型の降雨系の多くが孤立



Fig. 3. Frquency of east-southeastward moving hailstorms (1960-1969). Only cases when the direction of movements were known are shown.

した山塊に発生していることも明瞭にあらわれている。 他に南進, 南々東進, 北東進型などについても頻度分 布を調べてみたが，ここでは言及しない。

これら進路別の分布図尔よび第 1 図から関東甲信地方 の雱道の分布をまとめてみたのが，第 5 図である。図中 太実線は雹道, 太破線は準雹道を表わす。第 1 図に扣け る頻度 5 日以上の地域もここに示した。

関東平野に拈ける雹道と準雹道の大部分が孤立した山 


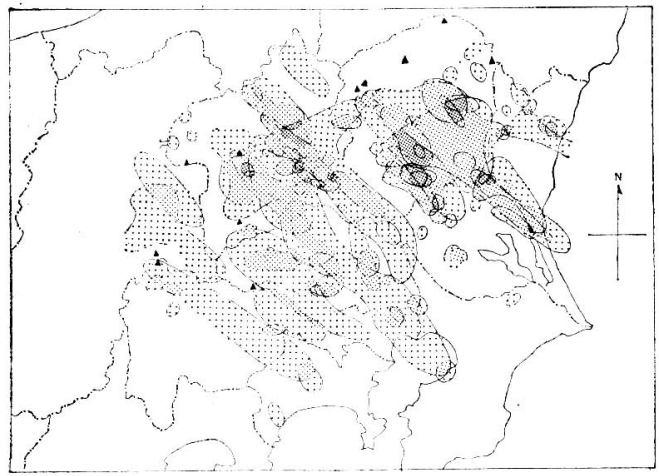

Fig. 4. Frequency of southeastward moving hailstorms (1960 -1969). Only cases when the direction of movements were known are shown.

塊から延びていることがこの図からよくわかる。すな わち(以下括弧内は第 5 図中0円内番号)，(1)一八溝 山；（2），（3）一高原山；（4），(5)一日光（男体山, 女峰) 山地；（7）一赤城山；(9)一榛名山；(11）一雲取 山；(19)一赤久䋲山の各山塊から，1ないし 2 筋の雱道
準雹道が延びている。このうち多くは以前から雷雲の通 路として知られており，地元民からは山の名を冠して八 溝雷, 高原雷, 日光雷などと呼ばれている。第 5 図中の （6）と（10）は，碓水峠を通過・あるいはこの付近に発 生した需雲によつて出来たものと考光られる。垰から出 てくる需雲と孤立した山塊に発生し平野に出てくるもの とでは，移動機構が少し異なるかも知れない。ただし （10）は浅間山付近に発生した䨠雲によるとも考えられ る。北信地方㧍よび土田・佐久盆地には，あまり明瞭に は分かれてはいないが，東進型と東北東〜北東進型の二 つの霨道が存在するようである。一般に山岳地帯では, 雹道は谷あるいは盆地にできる（７）南佐久；（8）沼 田盆地；(12）吾妻川上流；(18）甲府盆地）。

\section{4. 降雱系の移動}

なぜ雹道が存在するのか。それは，特定の地域霓雲 が発生し易く，径路む注ぼ決まつているからである。第 6 図に，1968年6月21日〜23日の3日間に発生した霉害 の分布とこれをもたらした需雲の移動方向を示した。こ の期間中に発生した雼雲は関東地方と甲府盆地では南東

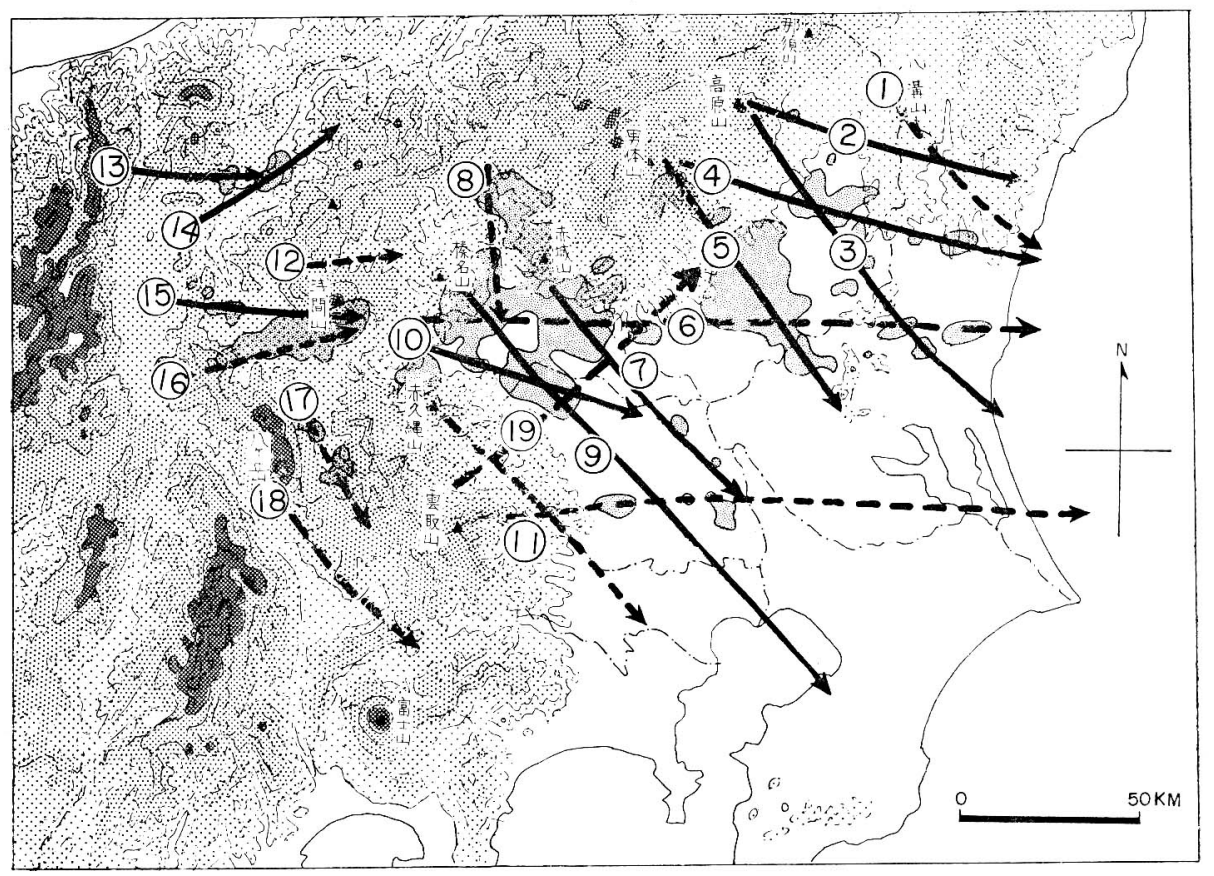

Fig. 5. Preferred routes of hailstorms or hailclouds in Kanto-Koshin region. Heavy lines are distinct routes (hyo-michi), and heavy broken lines are preferred routes of thunderstorms but frequency of hail occurrence along these are so small that these are called as jun-hyo-michi (secondary preferied routes of hailstorms). Stippled areas are where damaging hailstorms occurred more than 5 times for the 10 year period. 


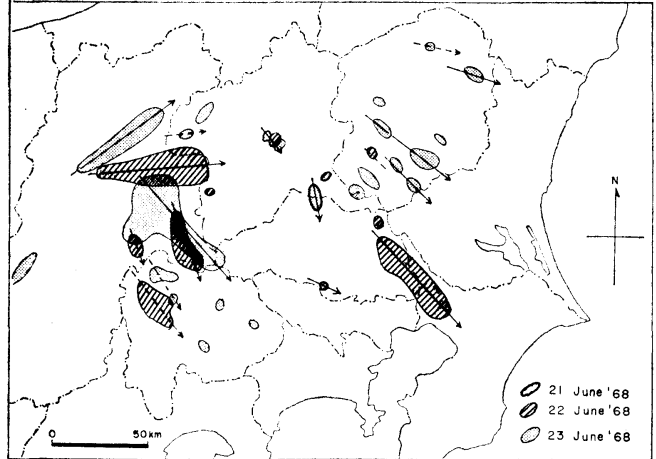

Fig. 6. Distribution of hail damage areas and the directions of movements of the hailstorms of $21-23$ june 1968 .

進，佐久盆地では東進，北信地方では北東進している。

第 7 図は,この期間の $9 \mathrm{~h}$ および $21 \mathrm{~h}$ における積乱雲 の雲底から雲頂までの大気層にほぼ相当する $900 \mathrm{mb}$
ら $300 \mathrm{mb}$ の間のベクトル平均風 $\overline{\boldsymbol{V}}$ である。平均風の流 線が非常に滑らかなことがこの図からよく分かる。22日 $21 \mathrm{~h}$ の館野の $\overline{\boldsymbol{V}}$ だけがやや異常な変化をしているがこ れは発達した局所あらしが観測時に付近にあつたためで ある。なお 23 日 $21 \mathrm{~h}$ 頃， $\overline{\boldsymbol{V}}$ 分布にも明瞭にあらわれる よらな強い上層の谷が通過した。この期間の降雹はこの 谷の前面, すなわち $\overline{\boldsymbol{V}}$ が西〜西南西の領域に発生した もので谷の通過後しばらくの間, 関東甲信地方には降雱 を伴う雷雨は発生しなかつた。

降雱や tornado を伴らような局所あらしの移動の機 構に関する研究はここ数年, 殊に盛んである。以前は, この種の対流系が $\overline{\boldsymbol{V}}$ に対して右に偏つて進むことが多 いことから, 右偏向の mechanism の解明が局所あらし の移動の mechanism の理解につながると考えられてい た。ところがこの数年間に, $\overline{\boldsymbol{V}}$ に対して左に偏つて進行 する局所あらしの存在が注目されはじめ,それまでの説 明をあらためて考え直す必要が生じた。局所あらしの移

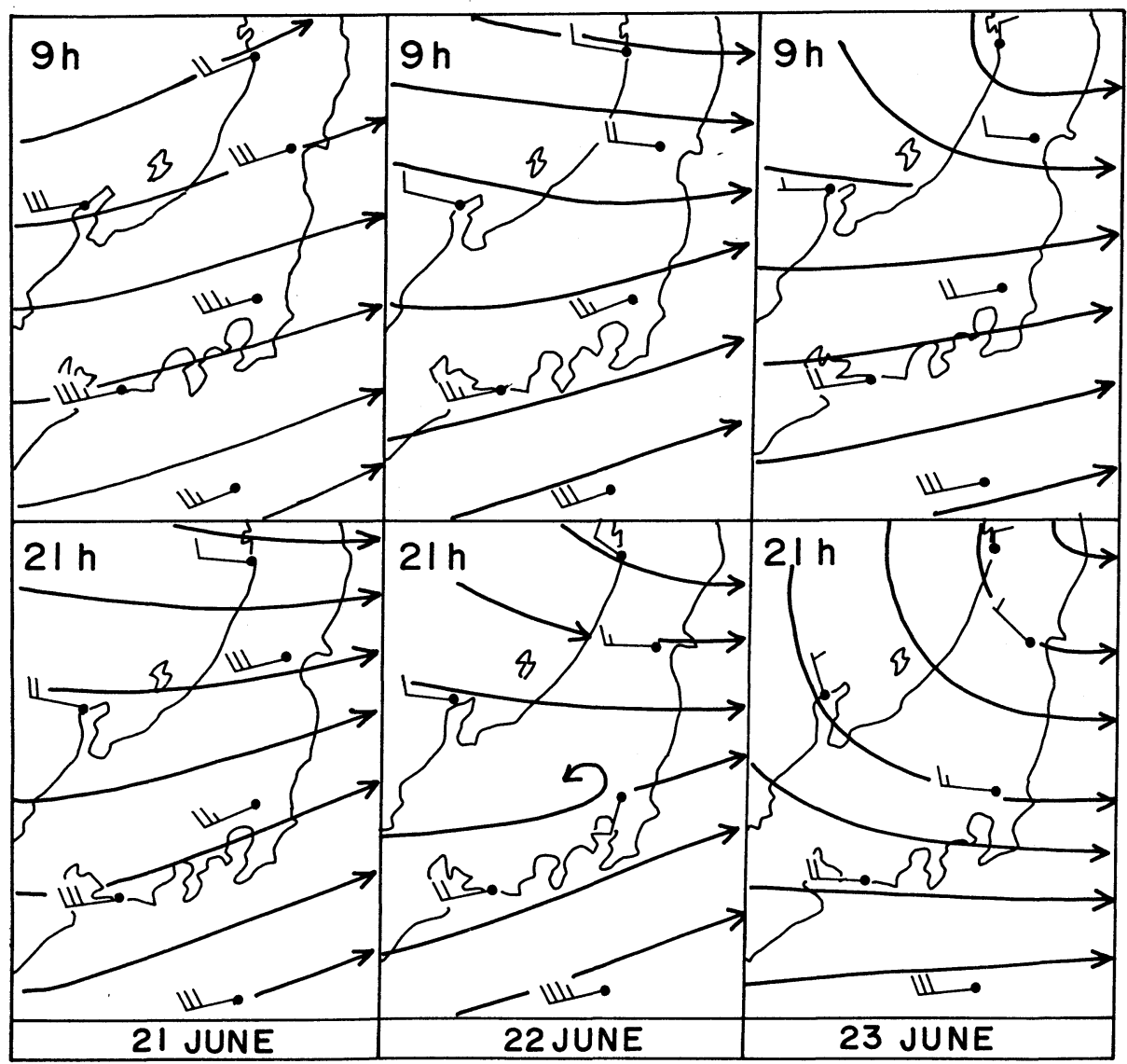

Fig. 7. Vertically averaged wind fields $(900-300 \mathrm{mb})$ over the eastern Honshu for the period 21-23 June 1968. 
動方向に影㬩を与えるものとして現在, 考学られている 主な mechanism は（1）激しい上昇流，下降流による 運動量の 垂直混合，（2）系の移動の伝播成分に寄与す る水蒸気供給の pattern 扎よび ( 3 ) 系の回転の三つで ある。これは，地形の影響の余りない米国中部大平原に 発生した例について調べられたものであり 22374)5)，地形 の影響はほとんど考慮されていない。

一方，第 6 図と第 7 図の比較加分かるように，関東 甲信地方の降雹系の移動方向は上層風または $\overline{\boldsymbol{V}}$ とは余 り関係がないよらである。問題の期間中に発生した降雹 系で南東進したものは右偏向型, 北東進したものは左偏 向型, 東進したものはほぼ $\overline{\boldsymbol{V}}$ の方向に移動したもので ある。各地に発生した降雱系はそれぞれの地域に执いて 頻度の最も多い方向に移動している。長野・山梨両県内 の各降雹系は，発生地域の雹道に沿つて移動して和り， 地形との関係は明瞭である。先にあげた三つの要素に加 えて地形の影響も考慮にいれる必要がある。筆者の知る かぎり, 今迄に関東甲信地方の降雱系の移動の詳細観測 は行なわれていない。先ず,この地方における降雹系の 移動を詳細に観測しなければなるない。

\section{5. 降雹頻度分布の変動}

この報告の頻度分布（第 1 図）と第 1 報の第 4 図に示 した頻度分布ての両者にあらわれた極大の位置は大体に おいて一致するが，今回の調查で明暸な極大のうち，北 信地方, 埼玉県東南部，および南作久の極大は前報の分 布には流とえど顕われていない。前報のは地域頻度分布 であつて，今回のと分布図の作成法に差はあるが，上述 の違いは期間の取り方の相異によるものである。前報の は1960-67年の8 年間のものであり，今回のはそれに 2 年加壳た69年迄のものである。

この変動を更に詳しく調べるために, 刘象とした10年 間を 3 期に分け, 各々についての頻度分布図を作り, 比 較，検討した（すなわち，第 I 期（1960-62）；第 II 期 (1963-66) ; 第 III期 (1967-69))。第 8 図は各期別に作 成した頻度分布図で，北関東と長野県中部以北の部分を 示した。北信地方沶よび南佐久地方では第 III 期に降雱が 殊に多からたことがよく分かる。その他, 注目される地 域 2,3 にいて述べると, 上田・佐久盆地では第 I 期

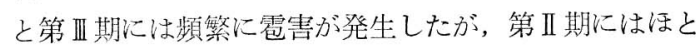
んど発生しなかつた。栃木県東南部では第Ｉ期にはあま

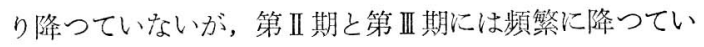
る。全期間をと打して常に降䨚回数が多かつた地域は, 群馬県南東部から埼玉県北部にかけての一带だけであつ た。変動が少なかつた理由として，第５図から分かるよ

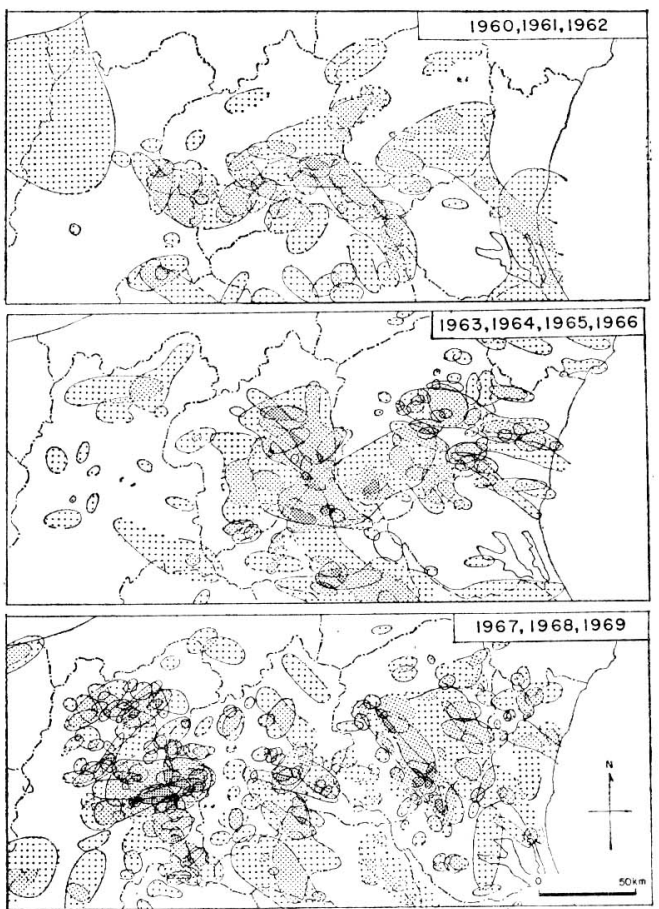

Fig. 8. Distribution of number of hail days of Northern Kanto for three periods. Period I (1960-62) : Period II (1963-66) : and Period III (1967-69).

らに, この地域が東進型, 東南東進型, 南東進型, およ び極めてまれではあるが北東進型の䨠雲の通路にも当つ ていることが考えられる。

信頼できる資料が得難いことから，長期にわたる頻度 分布の変化は海外でもあまり調べられていないよらであ る。Stout and Changnon (1968) $)^{8)} 1901 \sim 1960$ 年の 60年間を10年ごとに 6 期に分けて，米国中部の降雱頻度 分布を調べた。全期通しての頻度分布にあらわれた計 27 力所の極大のうち，6期全部に著しい極大としてあらわ れた地域は僅か 3 カ所にすぎなかつた。それほど明瞭で ない時期もあるが一応，安定した極大は 10 力所であつ た。一方，27力所の極大の中には，わずか $2 \sim 3$ 期に極 大となつただけで他の時期にはかくべつ多くも降らなか つたといらのが 6 力所あつた。以上のことから，10年程 度の資料では長期変動を知るのは困難であると推測され る。彼等の分布図は，わが国でいえば区内観測所クラス の観測所資料から求めたものである。関東地方の気象官 署扎よび区内観測所 1 力所当りの平均面積 $(\bar{A})$ は約 $250 \mathrm{~km}^{2}$ であるのに刘し，彼等の調査では $\bar{A}$ は 3000 $\mathrm{km}^{2}$ 以上であり, 関東地方の気象官署だけの平均分布 
密度よりも粗い資料を用いている。各期別の分布図には 観測所の位置や観測担当者が途中でかわつたために生じ た変化もある。明らかにそれと分かるものもあるが，中 には自然変化と見分けがつきかねるものもある。Changnon (1969) はまた, 米国イリノイ州中部にある非常に


それによると，観測所の平均間隔が $3 \sim 4 \mathrm{~km}(\bar{A} \doteqdot 10$ $\left.\mathrm{km}^{2}\right)$ と $20 \sim 30 \mathrm{~km}\left(\bar{A} \doteqdot 500 \sim 1,000 \mathrm{~km}^{2}\right)$ とでは分布 がかなり違つてくることがわかる。長期に亘つてはこの 様に密な観測網による資料がないので, 降雨発生頻度分 布の長期変動を調べることは極めて難しい。

\section{6. あとがき}

関東甲信地方には降雹系が周辺に較べて比較的頻繁に 通過する地帯, つまり需道が実際に存在することを確認 した。雹道は山岳地带では盆地や谷沿いに出来る。関東 平野の䨚道の多くは北関東の孤立した山塊から延びてい る。これらの䨞道のほとんどは, 以前から雷雲の通路と しても知られている。谷沿いに雹道ができやすい理由と して, 雹雲が摩擦の大きい山を避け, 低地沿いに移動す ることが考えられる。なぜ孤立した山塊から平野に向つ て 1 または 2 筋しか雹道が延びないか, 現時点では説明 できない。

報告される降雹分布には人為的な影響がでてくる。人 口稠密地带や農耕地に降つた雹はたいてい報告される が，山林などに降つた場合は報告されずに終わることも ありらる。雹 (雷) 雲の移動方向が 8 方位で報告される ために,これらの方向が頻繁にでる可能性もある。しか 乙第 1 図に顕われた筋状分布はこれとは全く無関係であ

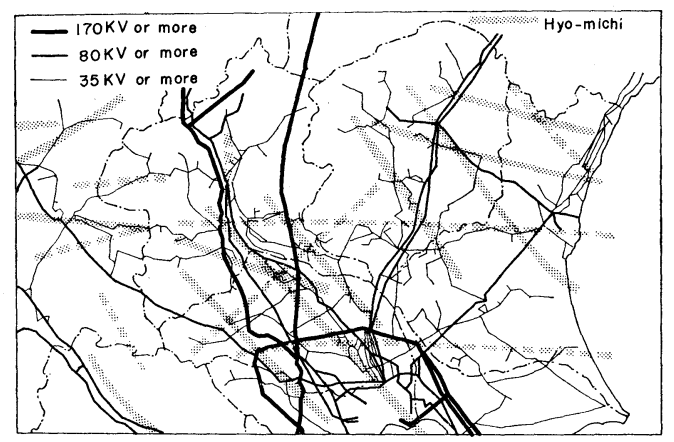

Fig. 9. Distributions of high-voltage power lines and hyo-michi (preferred routes of hailstorms).
る。高圧線に沿つて雹道が出来るといらことをたびたび 耳にしたので, 調べてみた。第 9 図は高圧送電線と雱道 の分布図である。群馬県南部や埼玉県北部では, 䨠道が 高圧線に沿つているかの如く見える地域もあるが, 部分 的であり, 関東全域についてみると, 両者のあいだに関 係はないといつたほらが妥当であろら。雹が雷雲に伴 い, 送電線と雹雲の間に電気的な関係がありそうに思わ れることから,たまたま雹道と送電線が並行している地 域の人々が，両者の間に関係があると考えちがいしたの であろう。

今回の研究で雹道の位置を検出することは出来たが, その 形成機構について満足すべき説明は得られなかつ た。既存の資料を使つて上述以上の結果を求めることは 困難であろう。雹道が何故できるかを理解するにはどう しても, 霓雲の特別観測を行ない, その行動を詳細に調 ベなければならない。

\section{引用文 献}

1) Changnon, S.A., 1969 : Hail evaluation techniques. Final Rept. Part I NSF GA-482, Illinois State Water Survey, Urbana, Ill. 97 pp.

2) Chabra, J., and Y. Sasaki, '1968: Structure and movement of the severe thunderstorms of 3 April 1964 as revealed from radar and surface mesonetwork data analysis, ERLTMNSSL No. 41, 47pp.

3) Fujita, T., and H.Grandoso, 1968 : Split of a thunderstorm into anticyclonic and cyclonic storms and their motion as determined from numerical model experiments, J. Atmos. Sci., 25, 416-439.

4) Newton. C.W., and J.C.Fankhauser, 1964 : On the movement of convective storm with emphasis on size discrimination in relation to water-budget requirements. J. Appl. Meteor., 3 651-668.

5) Newton, C.W., and H. R. Newton. 1959 : Dynamic interactions between large convective clouds and environment with vertical shear, J.Meteor., 16, 483-496.

6) Омото, Y., 1967 : Characterics of hailstorms in Japan. J. Agr. Meteor., 23, 115-121.

7）小元敬男, 1968 : 関東甲信地方の降ひょ5につ いて (1) 農業気㷪 24, 33-38.

8) Stout, G.E., and S.A.Changnon, Jr., 1968 : Climatology of hail in the Central United States. CHIAA Res. Rept. No. 38, 49pp. 


\section{Summary}

Farmers in some regions of the Northern Kanto believe existence of so called hyo-michi (hail street or road of hail), along which hailstorms pass frequently. They say a hyo-mich locates along a river, or a valley or a high-voltage power line. Neither reasons for formation nor the existence itself of hyo-michi have been scientifically investigated. Determination of such preferred routes of hail clouds is very useful in making plans for field observations and modification experiments of hailstorms.

In this study attempts are made : (1) to determine locations of hyo-michis, (2) to study reasons for formation of such preferred routes of hailstorms, and (3) to examine year to year variation of frequency distributions of hail occurrence. The results are as follows :

(1) It is found out that most of hyo-michis in the Kanto-Koshin plains originated from relatively isolated mountains or mountain groups. But in mountaneous regions, they are located along long axes of elongated basins or sometimes originated major mountain passes (Fig. 5). Hyo-michis coincide with preferred routes of thunderstorms. It is found out that only in a small areas parailelizm between hyo-michi and high voltage power lines exists. Generally speaking there is no special relation between them.

(2) It is pointed out that movements of hailstorms is strongly influenced by orography in mountaneous regions. The directions of movements of hailstorms developed 21-23 June 1968 (Fig. 6) are compared with the vertically averaged wind $(\bar{V}: 900-300 \mathrm{mb})$ field for the same period (Fig. 7 ). It is seen that storm movements were poorly related to the general $\bar{V}$ pattern. In mountain areas each storm moved more or less parallel to the preferred routes of the region it developed.

( 3 ) The 10 year period chosen for this study is devided into three periods : I) $1960-62$; II) $1963-66$; III) 1967-69 (Fig. 8). It is pointed out that a distinct hail maximum of northern Nagano Prefercture in the 10 year frequency chart (Fig. 1) is attributed to hailstorms of the period III only. In Ueda-Saku basin hail occurred frequently during the period I and II, but in the period II practically no hailstorm occurred in this area. Only region where hail occurrence was relatively uniform throughout the 10 year periods is southern Gunma northern Saitama region, where several hyo-michis with different orientations come togather. 